\title{
The association between values and performance in a mining corporation. Empirical study and insights for Managing by Values (MBV) model
}

\section{Introduction}

The article presents the model of mining enterprise values and the methods and findings of the research of the values it contains for two mining districts of different work efficiencies. The theoretical section refers to the description of values commonly applied in management; it presents the model of mining values generated in the management of the mining enterprise and the main hypothesis of the work refers to the relationship between mining values and the effectiveness of work in mining. The next section contains a description of a research method and its procedures and a manner for the selection of variables and the generation of the ratios related to them. Then, the presented findings show the difference in values present in the district featuring a higher mining efficiency compared to a district featuring a lower work efficiency; they also contain the research on the relationship between values, the level of the workers' satisfaction with the duties they perform and the perception of work at the district as efficient, punctual and disturbance-free. The main research limitations were highlighted in the conclusions and the follow-up work areas were indicated in the conclusions.

* Ph.D., Wroclaw University of Economics, Wroclaw University, Wrocław, Poland; e-mail: anita.zbieg@gmail.com

** Ph.D. Eng., Associate Professor, Wrocław University of Science and Technology, Faculty of Geoengineering, Mining and Geology, Wrocław, Poland; e-mail: jan.kudelko@pwr.edu.pl *** M.Sc., **** M.Sc. Eng., TECHBRAINERS Sp. z o.o., Warszawa; e-mail: a.juzyk@techbrainers.com;1.zaremba@techbrainers.com 


\section{Work Values in Mining}

\subsection{Managing by Values}

According to the Managing by Values concept (Managing by Values - MBV) (Dolan and Garcia 2002; Quinn et al. 1983), these values account for the core of the operation of an enterprise. Empirical research demonstrates that the majority of organizations and their cultures may be described using relatively simple models of values referring to the criteria for the assessment of the effectiveness of the functioning that allow for the determination of the main directions of activity and provide a core for long-term development (Quinn et al. 1983; Hofstede 2010). Therefore, the values of an enterprise consist of generally accepted principles and convictions about the sources of its effectiveness and the directions of aspirations that may provide the most general core for business management as they are a basis for the adopted manners of determining targets and the coordination of work and the standards of conduct. They determine the main sources of the value created by the enterprise and they are a determinant of the key directions of the organization's directions of actions as a whole as well as of the specific groups and employees that make it up. The main advantage of the organization, the culture of which is built by well-defined values is its skill to accept the necessity of a constant change and adaptation to the environment while maintaining the stability and sustainability in time on the basis of the identity that has been built over the years (Dolan and Garcia 2002).

The research shows that the organizational culture made up by its values, structure, manner of achievement of targets and organization of tasks, an organizational climate and individual convictions of workers is a source of a competitive advantage and effectiveness of many companies (Marocoulides and Heck 1993; Hartnell et al. 2011). Values also have a positive impact on such basic and countable aspects of work as efficiency and effectiveness of the performed tasks (Marocoulides and Heck 1993; Sheridan 1992), and the level of turnover of staff estimated for major enterprises in millions of dollars (Sheridan 1992).

The model that is frequently applied in managing by values is the Competing Values Framework (Quinn et al. 1983; Cameron and Quinn 2011), which provides a basis for a majority of the on-going work. The values distinguished in this model are: cooperation (cooperate), control (control), competition and competitiveness (compete) or creation and innovation (create). The values of the model compete with each other, which means that there is usually one type of values prevailing in an organization and it describes the criteria of effectiveness and the manners of achievement of success on the basis of two dimensions: a dimension of orientation on internal issues vs. a position in the environment and a dimension referring to the manners of operation: flexibility, self- reliance and dynamism vs. consistency, order and control. Such a model makes it possible to determine whether an organization has the features of the clan culture, hierarchy culture, market culture or adhocracy culture and its detailed components are presented in Table 1. 
Table 1. Main features of the Competing Values Framework

Tabela 1. Główne cechy modelu wartości konkurujących

\begin{tabular}{|c|c|c|c|}
\hline Clan Culture & Hierarchy Culture & Market Culture & Adhocracy Culture \\
\hline $\begin{array}{l}\text { Prevailing value: } \\
\text { cooperation }\end{array}$ & $\begin{array}{l}\text { Prevailing value: } \\
\text { control }\end{array}$ & $\begin{array}{l}\text { Prevailing value: } \\
\text { competition }\end{array}$ & $\begin{array}{l}\text { Prevailing value: } \\
\text { creation }\end{array}$ \\
\hline $\begin{array}{l}\text { Leader: advisor, mentor, } \\
\text { father }\end{array}$ & $\begin{array}{l}\text { Leader: coordinator, } \\
\text { organizer, observer }\end{array}$ & $\begin{array}{l}\text { Leader: tough and } \\
\text { demanding, supervisor, } \\
\text { competitor, manufacturer }\end{array}$ & $\begin{array}{l}\text { Leader: innovator, } \\
\text { entrepreneur, visionary }\end{array}$ \\
\hline $\begin{array}{l}\text { Dominant principle: } \\
\text { doing things together }\end{array}$ & $\begin{array}{l}\text { Dominant principle: } \\
\text { doing things properly }\end{array}$ & $\begin{array}{l}\text { Dominant principle: } \\
\text { doing things fast }\end{array}$ & $\begin{array}{l}\text { Dominant principle: } \\
\text { doing things before } \\
\text { others }\end{array}$ \\
\hline $\begin{array}{c}\text { Sources of effectiveness: } \\
\text { coherence, morale, } \\
\text { human development }\end{array}$ & $\begin{array}{l}\text { Sources of effectiveness: } \\
\text { efficiency, punctuality, } \\
\text { disturbance-free work }\end{array}$ & $\begin{array}{l}\text { Sources of effectiveness: } \\
\text { share in the market, } \\
\text { competitiveness, target } \\
\text { achievement }\end{array}$ & $\begin{array}{c}\text { Sources of effectiveness: } \\
\text { innovative product, } \\
\text { effectiveness }\end{array}$ \\
\hline $\begin{array}{l}\text { Target: an aspiration to } \\
\text { increase involvement of } \\
\text { people }\end{array}$ & $\begin{array}{l}\text { Target: an aspiration to } \\
\text { manufacture identical } \\
\text { products }\end{array}$ & $\begin{array}{l}\text { Target: an increase of } \\
\text { competitiveness and } \\
\text { effectiveness }\end{array}$ & $\begin{array}{l}\text { Target: the creation of } \\
\text { products and services } \\
\text { before competition }\end{array}$ \\
\hline $\begin{array}{l}\text { Management rule: } \\
\text { participation supports } \\
\text { involvement. } \\
\text { Management: teams, } \\
\text { human relations, } \\
\text { development of } \\
\text { employees }\end{array}$ & $\begin{array}{l}\text { Management rule: } \\
\text { control supports } \\
\text { effectiveness. } \\
\text { Management: } \\
\text { assimilation, control } \\
\text { system, coordination }\end{array}$ & $\begin{array}{c}\text { Management rule: } \\
\text { competition supports } \\
\text { effectiveness. } \\
\text { Management: } \\
\text { competitiveness, } \\
\text { encouraging employees } \\
\text { and customer oriented } \\
\text { attitudes }\end{array}$ & $\begin{array}{c}\text { Management rule: } \\
\text { innovation supports } \\
\text { acquisition of resources. } \\
\text { Management: } \\
\text { innovation, on-going } \\
\text { improvement, oriented } \\
\text { towards the future }\end{array}$ \\
\hline
\end{tabular}

Based on Cameron and Quinn 2011.

\subsection{Mining Values - Values Unique for Mining Work}

Due to the specific nature of work in a mining enterprise (Kudełko et al. 2011), operating in a local environment that involves confrontation with natural elements that entail some risks being simultaneously a source of wealth to be mined, the values of work referred to by miners (Zbieg et al. 2016) focus on the aspects different than the conventional values applied in management (Quinn et al. 1983). When asked about what is important for the efficient performance of work in mining, the supervisors indicate a number of values unique for the mining industry or that are specifically performed in mining which are not taken into account in conventional models. These values in the research of a mining enterprise (Zbieg et al. 2015) turn out to constitute a consistent system of interrelated components to a higher degree than conventionally understood work values. Apart from the fact that their occurrence has been confirmed, unique mining values have also been related to the feeling of location of control 
and the manner of perceiving nature. These values include the nature treated as wealth and as a hazard and a human being epitomizing the value of life and human work accounts for the ultimate mining value (Zbieg et al. 2015; Zbieg et al. 2016). These values are targets in themselves they build up the major dimensions of work involved in mining and drive the targets of mining activity. In order to implement them efficiently, five instrumental values were distinguished that enable the achievement of the ultimate values.

\section{Protection Achieved by Safety}

Safety supports protection. This means a lack of risk from nature that is meant not only to protect life but also to keep mining operations going as it is impossible to work in the situation of risk or emergency. Protection may also be increased by (1) on-going consideration of the others i.e. the awareness that the working conditions of colleagues depend on what I do or what I do not do; (2) risk reduction by performing tasks in a proper manner: pursuant to procedures, provisions, rules and practices developed over the years. Furthermore, an other important aspect is (3) the provision of proper information and acting pursuant to the rule: "prevention is better than cure": informing about any changes and undertaking actions immediately. Protection is also performed by on-going risk assessment, i.e., foreseeing a risk on the basis of even the smallest of signals.

\section{Obedience Achieved by Discipline}

Discipline supports obedience. This means strict rules of conduct and the unquestionable way of performance of orders and procedures. Obedience is required in order to be able to handle risks and difficult working conditions successfully and collectively. Obedience means (1) subordination i.e. acting pursuant to the superiors' decisions, but also (2) subordination to the targets of the entire group and, last, but not least, (3) on-going training in order to behave and do things in a proper manner.

\section{Practical Knowledge Achieved by Experience}

Experience supports gaining knowledge. Practical knowledge is the sum of information and skills obtained on the basis of observations and particular personal experiences acquired over the years of practice that are referred-to as overall experience. Such professionalism is achieved by: (1) the years of service and practice, but mainly by (2) the acquisition of expertise in the unique nature of a job related to the features of a rock mass that reduces the probability of making mistakes. Experience is valued as mining work is performed in variable and not totally foreseeable conditions and often requires instantaneous decisions; experience increases the probability that the decisions will be right.

\section{Trust Achieved by Responsibility}

Responsibility supports trust. It is an obligation of being responsible for your own or somone's else's actions that builds up trust i.e. the conviction that somebody's words and provided information is true, and actions are performed correctly. Trust is built on the fol- 
lowing: (1) a conviction that there are no errors: safety rules are followed, undertaken decisions are the best of the best, tasks are performered in the best possible manner and the information received is true and (2) in a situation of risk - certainty that others will help obtained from the observations of colleagues' behaviors.

\section{Courage and Exceptionality Achieved by Mining Tradition}

Mining tradition supports the acquisition of bravery and a feeling of being unique. Bravery is a daring and informed attitude to a risk, exceptionality is a conviction that you are special because of a job that you do. Both are achieved in the conviction that (1) mining is a form of heroism related to performing a job that involves hazards, fight, challenges and facing an element ; (2) mining is a profession advantageous for the public, not only for an individual; a profession that features the missionary feeling. Exceptionality that comes from the feeling of (3) working in the mining industry is a source of respect and esteem from your community, especially the local community.

\subsection{Conventional Work Values Implemented Specifically in the Mining Industry}

Apart from the values that serve superior activities which the mining work involves, i.e., efficient extraction of the wealth provided by nature in consideration of the related risks and protection of human life, the mining work involves the values that are conventionally used in management: cooperation, control, competition and creation (Cameron and Quinn 2011). They are mainly related to the manner of coordination of work, the source of its effectiveness and the manner of managing and leadership and they do not seem to compete with each other in the way they do in a classical model.

\section{Interrelation - Cooperation in Mining}

Cooperation in a mining enterprise is, to a large extent, of an interrelation nature, i.e., being dependent on the actions of others. To a lesser extent it is understood conventionally as a joint, collective undertaking of actions with others. Interrelation features the dependence of the workers' tasks; without performing one task, it would be difficult to perform subsequent ones, although sharing information between colleagues seems to be significant here. Interrelation is also well described by a metaphor of a machine in which every cog counts, but its operation depends on the operation of other little cogs.

\section{Supervision - Control in Mining}

Control in a mining enterprise is, in its nature, supervision as to whether the tasks were performed properly and is equivalent to conventional control to the highest degree. The manner of coordination of the work is based on the transparency of a structure, the clearly delegated responsibility and decision-making powers and the clarity of given instructions 
that enable verification at, practically, every level; such an approach highly contributes to the effectiveness of the work performed when facing a risk. Each worker has a clearly defined scope of responsibilities and knows what is within his powers. It increases foreseeability and stability, and thus improves the safety and effectiveness of work.

\section{Comparisons - Competition in Mining}

Competition is a race of who comes first and that, to a lesser extent, seems to be based on a classical understanding of competition as a reliable comparison of performance in a mining enterprise as performance is often assessed relative to the area of extraction where operations of various groups overlap. Apart from the comparison of work performance, comparisons between tasks groups occur as well as a feeling of higher significance of labor of some groups relative to others.

Improvements - Creation in Extraction

Creation is a possibility of the implementation of new solutions that is understood in a mining enterprise as the creation of minor, but well-thought improvements, not groundbreaking innovations. It is acting in "a plotted framework" of regulations, procedures, standards, principles and rules effective in mining work. It is often related to the image of an organization and own work as technologically advanced.

\subsection{Research Hypotheses}

The study is aimed at finding an answer to the question as to the relationship is between the aforementioned mining values and the quality of work of a mining district defined by the effectiveness of mining. The authors assume that the presence of the value of labor may be significant both at the level of the real work of a group, and at the level of perception of work by specific workers; they give rise to basic research hypotheses:

H1: Presence of mining values is positively related with the level of performance of work in the mining district.

$\mathrm{H} 2$ : Presence of mining values in a mining extraction is positively related with a feeling of efficiency of the work of a group as felt by workers.

H3: Presence of mining values in a mining extraction is positively related with the work and performed tasks as felt by workers.

The expectation was that there would be major differences in the level of mining values in the districts featuring various efficiency of mining, but the district of higher efficiency would be at a higher level. It was also expected that the presence of values conventionally used in management in a mining district would be less related with the level of performing work than in the case of mining values. 


\section{Method}

The experiment performed in one of the mining enterprises operating for several years would be aimed at providing a reply to the question about the relationship between the presence of values of work in the district and the effectiveness of mining. The research covers a questionnaire survey to measure mining values in districts featuring geological and geographical conditions of work and a number of workers, featuring a varied mining efficiency.

\subsection{Participants}

The workers in mining districts were selected for the research. The analyzed groups are blue-collar workers working directly in mining $(\mathrm{N}=193)$. The number of workers was: 99 persons from district 1 and 94 persons from district 2, respectively. The surveyed persons come from 4 work shifts in the mine and work both during the day and at night. The survey sample, therefore, reflects "a day of work in a mine" ensuring a relatively good representation for all workers who work in districts 24 hours of a day. The surveyed persons are men 23-52 years of age with the average age being $38(\mathrm{SD}=6.90)$. The information about the age and the years of service was obtained from an incomplete group $(65 \%$ sample i.e. 126 persons) with a deviation within the range of 1-10 years and 5 years being an average $(\mathrm{SD}=2.4)$. The database was formerly used for calculations pertaining to statistical features of a generated questionnaire of values (Zbieg et al. 2015).

\subsection{Procedure}

In October 2012, as instructed by district managers, the foremen of both mining districts distributed the following among workers: te Mining Values Scale (MVS) (Zbieg et al 2015) and the Organizational Culture Assessment Questionnaire applied widely in management (Cameron and Quinn 2011). The question was asked about satisfaction from work and asked the workers to state their opinion on the following statement: I am happy with tasks entrusted to me, the work atmosphere, the team in which I work and the work I perform, as well as about the efficiency of work in a group that was described by the following statement: My colleagues efficiently perform their tasks, their work is usually punctual and disturbance-free. The statements in the Work Value Questionnaire in a Mining Enterprise were answered by the workers using the 6-grade Likert scale with forced selection (1-definitely "No", 6-definitely: Yes"), but relative to the statements of the Organizational Culture Assessment Questionnaire, they had a total of 600 points (100 points in each point to be divided between 4 statements each referring to a different value of work). They were also asked to provide their age, sex, years of service and occupied position. When leaving work, 
the workers were given questionnaires to take them home and were asked to bring them back completed on the next day. The reply ratio was $98 \%$ (3 sets contained incomplete replies and were not taken into account in the survey).

\subsection{Variables and Ratios}

The values declared by workers of both districts constituted one group of variables. They were expressed as: (1) mining values specific for the work in mining: Protection of life achieved by safety; Practical knowledge achieved by experience; Trust achieved by responsibility; and Bravery and exceptionality achieved by mining tradition; and (2) values being equivalents of values of a model of competing values specific for a mining industry: Cooperation achieved by interdependence; Control achieved by supervision; Competition achieved by comparisons; and creation achieved by improvements; and also as (3) values of a competing values framework conventionally used in management: Cooperation, Control, Competition and Creation. Additionally, the survey also takes the satisfaction declared by workers and their feeling that a group works efficiently into account.

Another group of ratios pertained to a variable being the effectiveness of mining that was expressed by the performance of the worker's work in districts in the period of 6 months (May-October), including: the drilling of blastholes [running meters per man-day]; anchoring [items per man-day]; rock loading and its hauling [runs per man-day]; and blasting operations [a number of blastholes drilled per man-day]. Ratios were built in the following manner: data pertaining to efficiency of work of every worker in a district of a given professional group (e.g. a number of blastholes for a blasting miner) was divided by the number of working days worked by this miner within 6 months. Table 2 presents the efficiency of works of districts as the average efficiency of work of all miners expressed in a given unit of effectiveness per one working day.

The values in the above Table 2 show that District 1 demonstrates better work performance measured by a majority of the performance ratios. In order to be able answer the question about the statistical significance of these differences, the ANOVA variance analysis was performed. In spite of the fact that the workers of both districts work in similar geographical and geological conditions, there are major differences between work performance.

In one day, the workers of District 1 drill blastholes in a significantly longer section WO: $\left(F(1.51)=44.82 ; p<0.001 ; \eta^{2}=0.47\right)$. The results present a statistically significant difference between means in observed mining districts. The F-statistic reflects the ratio of variation between - group variance and variation within - group variance with the corresponding degrees of freedom. The significance value $p$ is below 0.001 and, therefore, in this case there is a statistically significant difference in the WO - blasthole drilling in District 1 compared to District 2. The eta-squared $\left(\eta^{2}\right)$ gives additional information as a measure of effect size for ANOVA effects and explain what percentage of the variance was caused by the variable ( $47 \%$ in this case). 
Table 2. Average efficiency ratios of the work of two mining districts in 6 months

Tabela 2. Średnie wskaźniki wydajności pracy dwóch oddziałów wydobywczych przez 6 miesięcy

\begin{tabular}{|c|c|c|c|c|}
\hline & Measuring unit & District 1 & District 2 & $\%$ of changes \\
\hline WO - blasthole drilling & running meter/man-day & 402.0 & 356.5 & $11 \%$ \\
\hline \multicolumn{5}{|c|}{ Anchoring } \\
\hline K1 - SWK 1.8 expanding anchor & items/man-day & 24.3 & 20.8 & $14 \%$ \\
\hline K2 - SWK-F 1.8 expanding anchor & items/man-day & 39.4 & 29.8 & $24 \%$ \\
\hline K3-SWK-F 1.8 joining anchor & items/man-day & 29.9 & 25.4 & $15 \%$ \\
\hline SWK 2.6 joining anchor & items/man-day & 14.6 & & - \\
\hline K4 - SWK-F 2.6 joining anchor & items/man-day & 21.8 & 15.6 & $28 \%$ \\
\hline \multicolumn{5}{|c|}{ Rock loading and hauling } \\
\hline Average hauling distance (constant) & running meter & 687 & 365 & $47 \%$ \\
\hline $\mathrm{ZU}$ - average number of runs & runs/man-day & 31.7 & 35.6 & $12 \%$ \\
\hline \multicolumn{5}{|c|}{ Rock hauling } \\
\hline Average hauling distance (constant) & running meter & 992 & 1057 & $7 \%$ \\
\hline $\mathrm{OU}$ - average number of runs & runs/man-day & 17.7 & 12.5 & $29 \%$ \\
\hline \multicolumn{5}{|c|}{ Blasting operations } \\
\hline S1 - Manual blasthole loading & blasthole/man-day & 92.7 & 93.9 & $1 \%$ \\
\hline S2 - Mechanical blasthole loading & blasthole/man-day & 164.8 & 163.3 & $1 \%$ \\
\hline
\end{tabular}

The values marked in italics are treated as constant. They are not comparable or treated as the work efficiency ratio. This is an average hauling distance that shows the differences in the geographical and geological conditions.

$\mathrm{K}$ - anchoring process, SWK - self-propelling anchoring vehicle.

In one work day, they also install significantly more items of anchors regardless of their type $-\mathrm{K} 1:\left(F(1.125)=68.67 ; p<0.001 ; \eta^{2}=0.35\right), \mathrm{K} 2:(F(1.53)=49.97 ; p<0.001$; $\left.\eta^{2}=0.49\right), \mathrm{K} 3:\left(F(1.18)=5.36 ; p<0.05 ; \eta^{2}=0.23\right)$ i K4: $(F(1.28)=74.44 ; p<0.001$; $\left.\eta^{2}=0.73\right)$ and perform significantly more runs hauling rocks - OU: $(F(1.121)=9.23$; $p<0.001 ; \eta^{2}=0.18$ ), but they have a negligibly shorter way they have to run on average (992 running meters as a route that is 6\% shorter than 1057 running meters). In District 1 during a working day, the number of runs is lower on average ZU: $(F(1.43)=236,03$; $p<0.001 ; h^{2}=0.66$ ), but the workers of this district must run over a section twice as long in one run that their colleagues from District 2 (687 running meters as a route that is $88 \%$ longer than 365 running meters). There is not major difference in the number of blasting operation performed within one day between districts $-\mathrm{S} 1:(F(1.66)=0.39 ; p=0.534)$ i S2: $(F(1.46)=1.02 ; p=0.318)$. 
The level of absenteeism of workers in both districts was controlled, which is often used as a simple indicator of thededication of workers (Cascio 1991). No statistically-significant differences were recorded comparing both the number of days on a vacation leave $(F(1.1510)=0.002 ; p=0.963)$ and a number of days on sick leaves $(F(1.1510)=0.39$; $p=0.786)$ in both districts.

This means that in both districts, despite a similar dedication of workers, the work effectiveness is different. In District 1, there are significantly higher efficiency ratios for 6 out of 9 analyzed indicators: (1) blasthole drilling - an average length of the section of drills performer on a working day; (2) anchoring - the average number of installed anchors on a working day; and (3) rock hauling - the average number of runs with rocks performed in a working day. It made it possible to assume that this district features a higher work efficiency.

\section{Findings}

\subsection{Presence of Mining Values vs. District Mining Effectiveness}

\section{Mining Values}

Both districts significantly differ in the level of the universality of mining values analyzed jointly declared by workers and in most cases, the values are present to a higher extent in the district featuring higher work efficiency $\mathrm{F}(5.187)=2.857, p=0.01, \eta^{2}=0.07$, Wilk's Lambda $=0.92903$ ). The power of the effect of the occurrence of all values relative to work efficiency is approximately $7 \%$ of the explanation of the variability of theresults. The level to which specific values occur in both districts is presented in Fig. 1.

According to the assessment of workers from both districts, the value of trust achieved by responsibility is definitely more popular in District $\left(F(1.191)=7.467, p=0.006, \eta^{2}=0.04\right)$ and the bravery and exceptionality achieved by the mining tradition $(\mathrm{F}(1.191)=4.664$, $\left.\mathrm{p}=0.03, \eta^{2}=0.02\right)$. The statistics of differences between districts at the safety level $(\mathrm{F}(1.191)=$ $=1.967, \mathrm{p}=0.16$ ) are also close to the significance limit, higher in a district featuring higher efficiency. The value of obedience achieved by discipline has been observed to be at a similar level in both districts $(\mathrm{F}(1.191)=0.36, \mathrm{p}=0.54)$ as well as the practical knowledge achieved by experience $(\mathrm{F}(1.191)=0.54, \mathrm{p}=0.81)$.

\section{Values from Competing Values Framework of K.S. Cameron and R.E. Quinn}

Both districts do not differ significantly in a level of popularity of the values in the Competing Values Framework used wildly in management as declared by workers $(\mathrm{F}(4.188)=$ $=0.510, \mathrm{p}=0.72$, Wilk's Lambda $=0.98925)$. There are no differences between districts and the level of control and competition is significantly higher than a level of cooperation and creation. Analyzed districts differ, however, in the level of preference of these values 


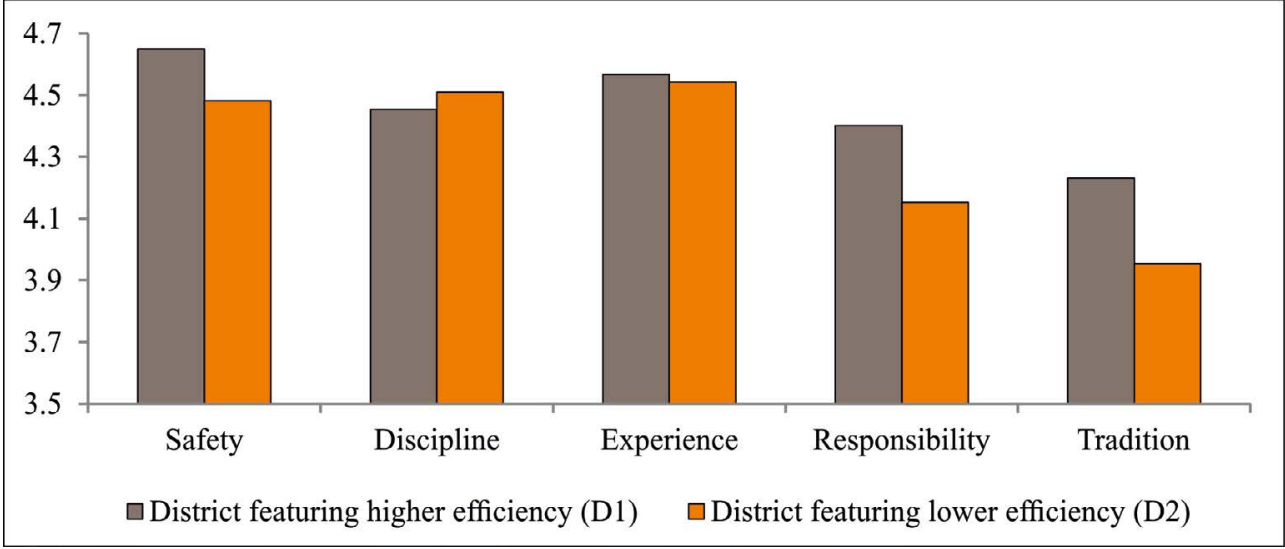

Fig. 1. Differences at the mining value level in district featuring various mining efficiencies

Rys. 1. Różnice w poziomie wartości górniczych na oddziałach o różnej wydajności wydobycia

$\left(F(4.188)=3.6784, p=0.006, \eta^{2}=0.07\right.$, Wilk's Lambda $\left.=0.92742\right)$ that arises from different preferences relative to control - workers of the district of lower effectiveness would like to have more than those workers of the more efficient district. Fig. 2 presents the level of conventional values in districts at present, and Fig. 3 refers to the preference of values that has been declared by workers.

Both districts implement the conventionally understood cooperation $(\mathrm{F}(1.191)=1.100$, $\mathrm{p}=0.29)$, and preferences in this value are similar $(\mathrm{F}(1.191)=0.629, \mathrm{p}=0.42)$. No differences between districts were observed for creation, neither currently $(F(1.191)=0.36, p=0.84)$, nor in the area of preferences $(F(1.191)=1.050, p=0.30)$. Conventional competition is also implemented $(F(1.191)=0.204, p=0.65)$ and desired $(F(1.191)=1.208, p=0.27)$ in a similar

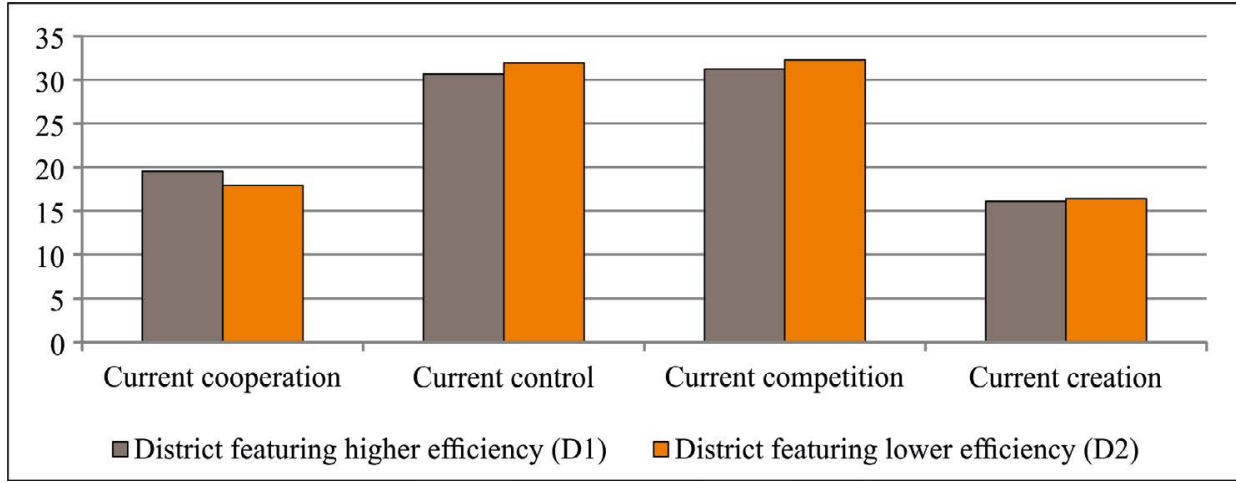

Fig. 2. The level of conventional values used in management in both districts

Rys. 2. Poziom klasycznych wartości wykorzystywanych w zarządzaniu na obu oddziałach 


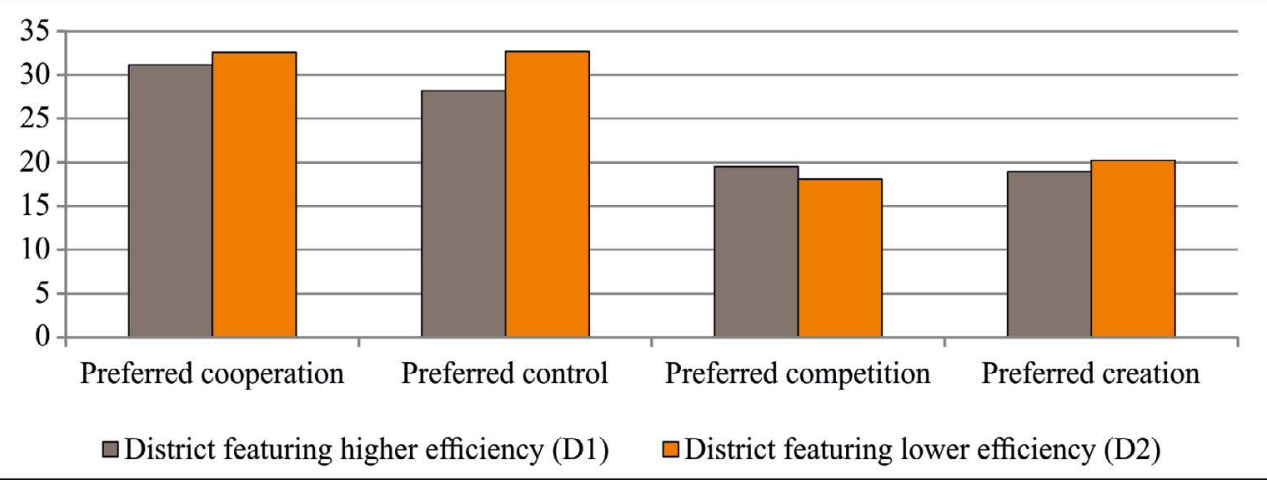

Fig. 3. The level of preference of workers relative to conventional values used in management in both districts

Rys. 3. Poziom preferencji pracowników względem klasycznych wartości wykorzystywanych w zarządzaniu na obu oddziałach

manner. As far as classical control is concerned, although it was declared in a similar man$\operatorname{ner}(\mathrm{F}(1.191)=0.3783, \mathrm{p}=0.53)$, although the workers in a district featuring higher effectiveness of work would prefer less of it $\left(F(1.191)=4.026, p=0.04, \eta^{2}=0.07\right)$.

Mining values equivalent of the values conventionally used in management

No differences were observed in the popularity of the occurrence of values of the Competing Values Framework, but these values, defined in categories of work in mining, differentiate surveyed districts $\left(F(4.188)=4.6067, p=0.001, \eta^{2}=0.09\right.$, Wilk's Lambda $\left.=0.91073\right)$, as presented in Fig. 4.

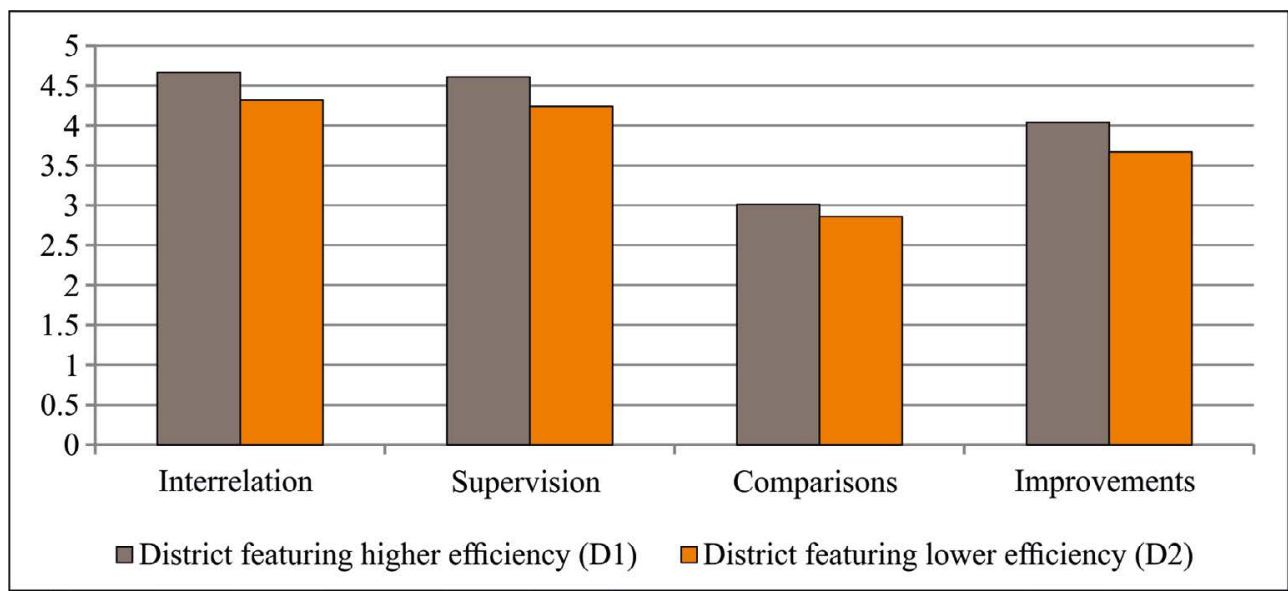

Fig. 4. The level of value of cooperation, control, competition and creation defined for mining in both districts

Rys. 4. Poziom wartości współpracy, kontroli, rywalizacji i twórczości zdefiniowanych dla górnictwa na obu oddziałach 
Three out of four of the analyzed values reach a higher level in the district featuring higher work efficiency: cooperation achieved by interdependence $(\mathrm{F}(1.191)=8.165, \mathrm{p}=0.005$, $\left.\eta^{2}=0.04\right)$, creation achieved by improvements $\left(F(1.191)=11.034, p=0.001, \eta^{2}=0.05\right)$ and control achieved by supervision $\left(F(1.191)=9.273, p=0.03, \eta^{2}=0.05\right)$. No significant differences were observed for competition achieved by comparisons $(\mathrm{F}(1.191)=1.676, \mathrm{p}=0.19)$.

\subsection{Presence of Mining Values vs. Work Satisfaction and the Feeling of Group Work Efficiency}

The workers in the district featuring higher efficiency of mining declared a higher level of satisfaction from work $\left(\mathrm{F}(1.191)=21.825, \mathrm{p}<0.001, \eta^{2}=0.10\right)$, i.e., were more happy with entrusted tasks, work atmosphere, the team and the performed work, felt more that the work in the district is efficient and disturbance-free $\left(F(1.191)=16.178, p<0.001, \eta^{2}=0.08\right)$, and thought that colleagues effectively perform their tasks and their work is usually punctual. Their level of satisfaction and level of perceived work efficiency in the group is presented in Fig. 5.

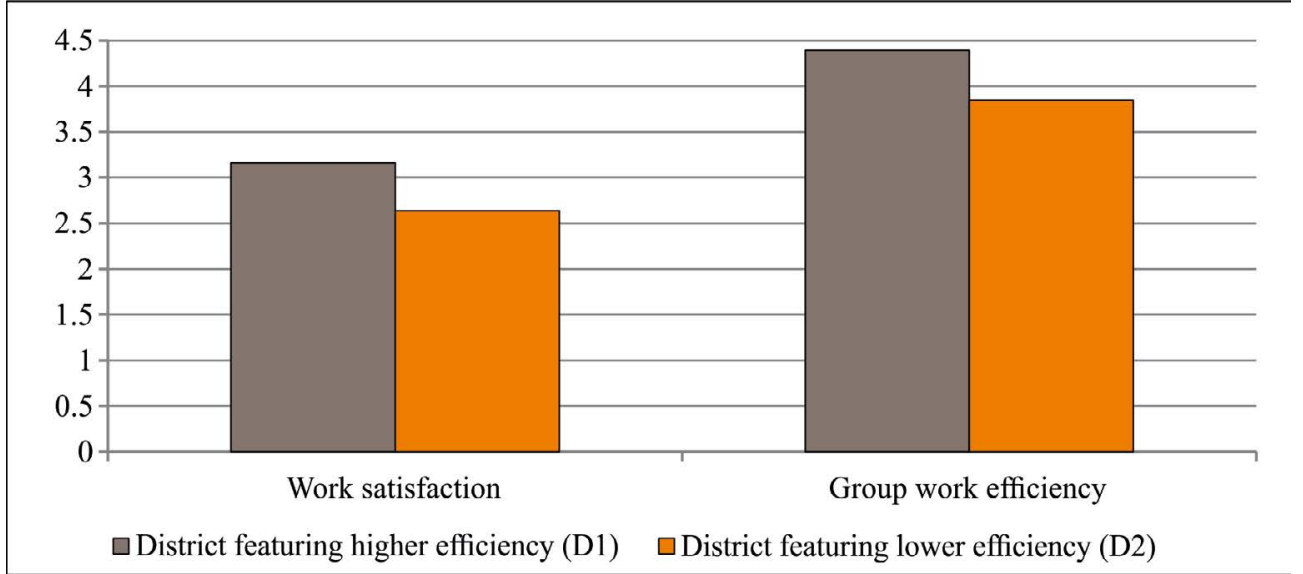

Fig. 5. The level of work satisfaction and group work efficiency perceived by workers of both districts

Rys. 5. Poziom poczucia satysfakcji i pracy bez zakłóceń wśród pracowników obu oddziałów

Both satisfaction from work and the feeling of efficiency of the closest task group may arise from the presence and implementation of mining values in the district (e.g., a higher level of the implementation of safety, responsibility or discipline in a group). This is the reason why the analysis of the power of the relationship of satisfaction from work and the feeling of work efficiency in the group with the level of popularity of values declared by workers (Table 3) was performed. 
Table 3. A relationship between mining values and satisfaction from work and a feeling of group work efficiency

Tabela 3. Związek wartości górniczych z satysfakcją z pracy i poczuciem sprawności pracy grupy

\begin{tabular}{|c|c|c|}
\hline & $\begin{array}{c}\text { Work } \\
\text { satisfaction }\end{array}$ & $\begin{array}{c}\text { Group work } \\
\text { efficiency }\end{array}$ \\
\hline \multicolumn{3}{|l|}{ Mining Values } \\
\hline Protection of life achieved by safety & $0.494 * *$ & $0.310^{* *}$ \\
\hline Obedience achieved by discipline & $0.262 * *$ & $0.375^{* *}$ \\
\hline Practical knowledge achieved by experience & $0.299 * *$ & $0.178 *$ \\
\hline Trust achieved by responsibility & $0.462 * *$ & $0.408^{* *}$ \\
\hline Bravery and exceptionality achieved by mining tradition & $0.370^{* *}$ & $0.288^{* *}$ \\
\hline \multicolumn{3}{|l|}{ Competing values defined for mining industry } \\
\hline Cooperation achieved by inter-dependence & $0.524 * *$ & $0.553^{* *}$ \\
\hline Control achieved by supervision & $0.500 * *$ & $0.277^{*} *$ \\
\hline Competition achieved by comparisons & -0.087 & $-0.207 * *$ \\
\hline Creation achieved by improvements & $0.428 * *$ & $0.258 * *$ \\
\hline \multicolumn{3}{|l|}{ Conventional competing values } \\
\hline Cooperation & $0.269 * *$ & $0.159 * *$ \\
\hline Control & -0.074 & $-0.174 *$ \\
\hline Competition & -0.116 & 0.043 \\
\hline Creation & $0.264 * *$ & 0.133 \\
\hline Feeling of disturbance-free work & $0.562 * *$ & \\
\hline
\end{tabular}

Pearson's correlation coefficients $(\mathrm{N}=193)$.

* Correlation is important at the level of 0.05 (two-way).

** Correlation is important at the level of 0.01 .

Relationships with satisfaction from work declared by workers and their feeling that the work in a district runs efficiently were observed among all the mining values. The more protection, obedience, knowledge, trust, bravery and exceptionality, the higher the level of satisfaction of a worker from their own work and colleagues' work. Interdependence and supervision and improvements are important at the level of coordination of the work in the district; only competition is rather negatively related with satisfaction and work efficiency. The values conventionally used in management often have a lower, and sometimes even a negative relationship with the feeling of satisfaction from their own work and the feeling of efficiency of work of the group. 


\section{Discussion}

Major differences were observed in the presence of mining values, which was graphically represented in Table 4 between districts of various effectiveness of mining. The findings suggest that the efficiency of work in mining operations is to some extent related to the presence of values of work in a task. Differences in the presence of all mining values are significant $\left(\mathrm{F}(9.183)=3.2774, \mathrm{p}=0.001, \eta^{2}=0.14\right.$, Wilk's Lambda $\left.=0.86119\right)$, and the power of effect of their presence in a district in terms of efficiency of work is about $14 \%$ of variability of results.

Table 4. Differences in values of work and the feeling of satisfaction and efficiency of work of a group in a district featuring higher efficiency of mining compared to a district of lower efficiency

Tabela 4. Różnice w wartościach pracy oraz poczuciu satysfakcji i sprawności pracy grupy w oddziale o większej wydajności wydobycia w porównaniu z oddziałem o mniejszej wydajności

\begin{tabular}{|c|c|}
\hline & $\begin{array}{l}\text { Mining district of higher } \\
\text { efficiency of mining }\end{array}$ \\
\hline \multicolumn{2}{|l|}{ Presence of mining values } \\
\hline Protection of life achieved by safety & $\uparrow$ \\
\hline \multicolumn{2}{|l|}{ Obedience achieved by discipline } \\
\hline \multicolumn{2}{|l|}{ Practical knowledge achieved by experience } \\
\hline Trust achieved by responsibility & $\uparrow^{*}$ \\
\hline Bravery and exceptionality achieved by mining tradition & $\uparrow^{*}$ \\
\hline \multicolumn{2}{|l|}{ Presence of competing values defined for mining industry } \\
\hline Cooperation achieved by inter-dependence & $\uparrow * *$ \\
\hline Control achieved by supervision & $\uparrow^{*}$ \\
\hline \multicolumn{2}{|l|}{ Competition achieved by comparisons } \\
\hline Creation achieved by improvements & $\uparrow * *$ \\
\hline \multicolumn{2}{|l|}{ Presence of classical competing values } \\
\hline \multicolumn{2}{|l|}{ Cooperation } \\
\hline \multicolumn{2}{|l|}{ Control } \\
\hline \multicolumn{2}{|l|}{ Competition } \\
\hline \multicolumn{2}{|l|}{ Creation } \\
\hline Feeling of satisfaction from work in workers & $\uparrow * *$ \\
\hline Feeling of disturbance free work in workers & $\uparrow * *$ \\
\hline
\end{tabular}

* Significant differences at the level of $<0.05$.

** At the level of $<0.005$. 
The levels of the following: cooperation achieved by inter-dependence, control achieved by supervision, creation achieved by improvements and trust deriving from responsibility, and bravery and exceptionality deriving from tradition and probably protection achieved by safety, are higher in the district that operates more efficiently. In both districts, the level of discipline and experience is similar, which seems justified by the fact that those values are deeply rooted in a formal aspect of the functioning of a mining enterprise. A long path of promotion, a long-term model of education in an organization, a strong hierarchy and a clear structure account for formal aspects of work that may ensure a similar level of achievement of both values across the entire enterprise. This does not mean, though, that they are not meaningful for the nature and effects of the performed work. The district featuring higher efficiency also enjoys the higher satisfaction of workers from their own duties and the feeling that their colleagues implement tasks efficiently. No differences occur in the presence of conventional values used in management between districts.

The aforementioned results demonstrate relatively powerful premises that the manner in which work is performed in a mining enterprise is highly related with the values present in a task group and that these values may have a significant impact on the quality of the performed work; thus, they should be intentionally maintained and managed. Therefore, it is likely that the surveyed district featuring the higher efficiency of mining is intuitively or intentionally managed with a higher degree of use of work values.

Also, a positive interrelation between presence of mining values in a district and the feeling of satisfaction with performed duties in a worker and a conviction that the work in his group runs equally efficiently has been confirmed. The case might be that the efficiency of work in a group is also affected by values in an indirect manner - the presence of values may improve the worker's satisfaction with their own work and the work of a group to which the worker compares himself, which, in turn, may increase their own effectiveness as well as the efficiency of the entire group on a larger scale. An interrelation of workers' satisfaction and their productivity has been indicated on numerous occasions (Cascio 1991); it suggests that further research of this mechanism is worth encouraging.

The findings of the survey suggest that a mining enterprise conducts such a unique business that the values distinguished in conventional models do not seem to be a fully adequate management tool. The values specific for the work in mining operation as presented in this article, if consistently developed and institutionalized (Stachowicz-Stanusch 2004), are likely to play this function and, in a long-term perspective may contribute to an increase of efficiency of mining as well as satisfaction from work and a feeling that it is implemented in a group in a proper way.

\section{Conclusion}

The article presents the findings of the survey of presence of work values in mining in two mining districts featuring various effectiveness of work. The results suggest that there 
is a relationship between the presence of values of work and the efficiency of mining operations of a district; they provide a premise that the implementation of a value as a component of mining enterprise business management makes sense. The presence of mining values in a district is not only related to the efficiency of work or a mining group, but also with an individual feeling of satisfaction in workers from the performance of tasks and the conviction that other members of a group perform their duties in an efficient manner. A major limitation of the survey is the fact that it was performed in the districts of one mining enterprise and in order to be able to draw general conclusions from the obtained results and apply them to a higher number of enterprises, some other surveys should be performed. In theory, however, the model of mining values presented in the survey was general enough that it should be applicable to the majority of enterprises performing work in mining that would be similar to the one described in the article.

\section{REFERENCES}

Cameron, K.S. and Quinn, R.E. 2011. Diagnosing and Changing Organizational Culture: Based on the Competing Values Framework, Jossey-Bass; 3rd edition.

Cascio, W.F. 1991. Costing Human Resources: The Financial Impact of Behavior in Organizations [W:] Kent Series in Human Resource Management, Pws Pub Co; 3rd edition.

Dolan, S.L. and Garcia, S. 2001. Managing by values. Cultural redesign for strategic organizational change at the dawn of the twenty-first century. Journal of Management Development Vol. 21, No. 2, pp. 101-117.

Hartnell et al. 2011 - Hartnell, Ch.A., Yi, Ou A. and Kinicki, A. 2011. Organizational Culture and Organizational Effectiveness: A Meta-Analytic Investigation of the Competing Values Framework's Theoretical Suppositions. Journal of Applied Psychology Vol. 96, No. 4, pp. 677-694.

Hofstede, H. 2010. Cultures and Organizations: Software of the Mind, Third Edition, McGraw-Hill; 3 edition.

Kudełko et al. 2011 - Kudełko, J., Juzyk, A. and Zaremba, L. 2011. Wpływ zarządzania przez wartości na efektywność przedsiębiorstwa górniczego, Przegląd Górniczy Vol. 67, No. 10, pp. 16-21 (in Polish).

Marocoulides, G.A. and Heck, R.H. 1993. Organizational Culture and Performance: Proposing and Testing a Model. Organization Science Vol. 4, No. 2, pp. 209-225.

Sheridan, J.E. 1992. Organizational Culture and Employee Retention. Academy of Management Journal Vol. 35, No. 5, pp. 1036-1056.

Stachowicz-Stanusch, A. 2004. Zarządzanie przez wartości. Gliwice: Wyd. Politechniki Śląskiej (in Polish).

Quinn et al. 1983 - Quinn, R.E., Rohrabaugh, J. and Spatial, A. 1983. Model of Effectiveness Criteria: Towards a Competing Values Approach to Organizational Analysis. Management Science Vol. 29, No. 3, pp. 363-377.

Zbieg et al. 2015 - Zbieg, A., Kudełko, J., Juzyk, A., Zaremba, L.P., Pałys, M. and Pałys, K. 2015. Identyfikacja wartości przedsiębiorstwa górniczego na potrzeby zarządzania przez wartości. Wiadomości Górnicze No. 10 (in Polish)

Zbieg et al. 2016 - Zbieg, A., Kudełko, J., Juzyk, A. and Zaremba, L. 2016. Wartości jako element zarządzania przedsiębiorstwem górniczym. Model i metoda pomiaru. Nauki o Zarzadzaniu No. 2/(23), pp. 127-146 (in Polish). 


\section{Attachment: \\ Work Value Questionnaire in Mining Plant}

The purpose of the study is to learn the valuable ways of working in your workplace. Try to answer questions as thoroughly and thoughtfully as you can. The survey is anonymous, and the analysis of the results is for the entire organization and everyone in it, and not for individuals. Any information that is likely to identify a particular person will be flushed or altered. You will find sentences that describe your workplace, the principles and values of your work, your team, and your colleagues. Indicate the extent to which you agree with these descriptions, or select the ones that best describe your workplace for each statement by sketching a number from 1 to 6 .

\begin{tabular}{|c|c|c|c|c|c|c|c|}
\hline & & 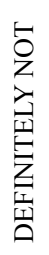 & $\stackrel{5}{\circ}$ & 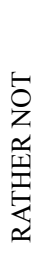 & 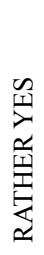 & $\underset{\nearrow}{\check{\nearrow}}$ & 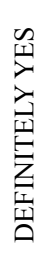 \\
\hline 1. & From my behavior, my health and my colleagues and my life depend heavily & 1 & 2 & 3 & 4 & 5 & 6 \\
\hline 2. & $\begin{array}{l}\text { For safety reasons, it is the most important thing to follow the procedures and } \\
\text { regulations }\end{array}$ & 1 & 2 & 3 & 4 & 5 & 6 \\
\hline 3. & $\begin{array}{l}\text { If the employee has false information about his or her job, it often leads to } \\
\text { dangerous situations }\end{array}$ & 1 & 2 & 3 & 4 & 5 & 6 \\
\hline 4. & We do not discuss with decisions and commands & 1 & 2 & 3 & 4 & 5 & 6 \\
\hline 5. & It is up to me and my colleagues to be subordinated and obedient & 1 & 2 & 3 & 4 & 5 & 6 \\
\hline 6. & We are accustomed to continuous training and training of others & 1 & 2 & 3 & 4 & 5 & 6 \\
\hline 7. & In the team we can not afford to make mistakes, so we focus on experienced people & 1 & 2 & 3 & 4 & 5 & 6 \\
\hline 8. & $\begin{array}{l}\text { You can not maintain safety without risk assessment, the skill that comes from } \\
\text { experience }\end{array}$ & 1 & 2 & 3 & 4 & 5 & 6 \\
\hline 9. & $\begin{array}{l}\text { Thanks to the knowledge of the rock and the specifics of work, a long-term } \\
\text { employee can effectively predict and prevent dangerous situations }\end{array}$ & 1 & 2 & 3 & 4 & 5 & 6 \\
\hline 10. & When one of my teammates is assigned a task, I am sure it will be done & 1 & 2 & 3 & 4 & 5 & 6 \\
\hline 11. & My associates are taking a firm stand in taking care of others & 1 & 2 & 3 & 4 & 5 & 6 \\
\hline 12. & Responsibility ensures security and builds trust, one of the most important things & 1 & 2 & 3 & 4 & 5 & 6 \\
\hline 13. & People in my group attach great importance to the mining tradition & 1 & 2 & 3 & 4 & 5 & 6 \\
\hline 14. & The work I do is more than hard work, it's respect and esteem of the milieu & 1 & 2 & 3 & 4 & 5 & 6 \\
\hline 15. & $\begin{array}{l}\text { People in my neighborhood consider me a hero, appreciate and respect our } \\
\text { profession }\end{array}$ & 1 & 2 & 3 & 4 & 5 & 6 \\
\hline
\end{tabular}




\begin{tabular}{|c|c|c|c|c|c|c|c|}
\hline & & 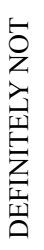 & 官 & 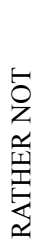 & 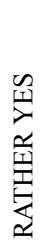 & 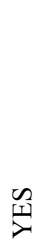 & 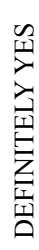 \\
\hline 1. & $\begin{array}{l}\text { The tasks I perform are strictly dependent on the tasks of other employees, } \\
\text { including those from other departments or divisions }\end{array}$ & 1 & 2 & 3 & 4 & 5 & 6 \\
\hline 2. & $\begin{array}{l}\text { My organization is like a machine where every mode is important, the work } \\
\text { of some groups or people here depends on the work done by others }\end{array}$ & 1 & 2 & 3 & 4 & 5 & 6 \\
\hline 3. & $\begin{array}{l}\text { To work well in the team was well done, we share information and work } \\
\text { together to figure out how to do things }\end{array}$ & 1 & 2 & 3 & 4 & 5 & 6 \\
\hline 4. & When the task is not done, we can easily find the person responsible for it & 1 & 2 & 3 & 4 & 5 & 6 \\
\hline 5. & $\begin{array}{l}\text { I have a clearly defined range of responsibilities, and the commands I make are } \\
\text { understandable }\end{array}$ & 1 & 2 & 3 & 4 & 5 & 6 \\
\hline 6. & $\begin{array}{l}\text { At my place of work there is a clear structure and hierarchy, it is known who is who } \\
\text { and who decides what decisions to make and who must carry out those decisions }\end{array}$ & 1 & 2 & 3 & 4 & 5 & 6 \\
\hline 7. & $\begin{array}{l}\text { When one job is done by people with different occupations, the work } \\
\text { of one is often more important than the work of others }\end{array}$ & 1 & 2 & 3 & 4 & 5 & 6 \\
\hline 8. & $\begin{array}{l}\text { I can indicate departments whose work is less important than the work } \\
\text { of the department to which I belong }\end{array}$ & 1 & 2 & 3 & 4 & 5 & 6 \\
\hline 9. & $\begin{array}{l}\text { More important than the ways of working are the results to be achieved } \\
\text { and they should be put in the first place }\end{array}$ & 1 & 2 & 3 & 4 & 5 & 6 \\
\hline 10. & $\begin{array}{l}\text { Improvements resulting from the experience and years of work are in my team } \\
\text { realized and appreciated }\end{array}$ & 1 & 2 & 3 & 4 & 5 & 6 \\
\hline 11. & $\begin{array}{l}\text { The organization is developing with a new solutions and better execution } \\
\text { of existing processes }\end{array}$ & 1 & 2 & 3 & 4 & 5 & 6 \\
\hline 12. & At my workplace, the world's newest technologies in our field are intertwined & 1 & 2 & 3 & 4 & 5 & 6 \\
\hline
\end{tabular}


ZWIĄZEK WARTOŚCI Z WYDAJNOŚCIĄ W PRZEDSIĘBIORSTWIE GÓRNICZYM. BADANIA ODDZIAŁÓW GÓRNICZYCH I PRZESŁANKI DLA ZARZĄDZANIA PRZEZ WARTOŚCI

\author{
Słowa kluczowe \\ zarządzanie przez wartości, przedsiębiorstwo wydobywcze, górnictwo, \\ rozwój firmy, model zarządzania, wydajność pracy
}

\title{
Streszczenie
}

Artykuł przedstawia wyniki badań obecnego poziomu wartości pracy górniczej i występujących w nim różnic dla dwóch oddziałów wydobywczych o podobnej charakterystyce geologicznej, jednak odmiennej efektywności pracy. W tym celu wykorzystano dwa rodzaje wskaźników badania wartości: wartości pracy w zakładzie górniczym oraz badanie klimatu i kultury organizacyjnej. Pięć z dziewięciu analizowanych wartości w istotny sposób różnicuje oddziały i jest wyższa w oddziale o większej wydajności pracy. Pomiędzy oddziałami nie występują natomiast różnice poziomu wartości klasycznie wykorzystywanych w zarządzaniu. Wyniki te sugerują, że funkcjonowanie oddziału wydobywczego może mieć istotny związek z obecnością wartości specyficznych dla górnictwa, które to mogą znacząco wpływać na jakość wykonywanej pracy. Ponadto, obecność wartości na oddziale ma pozytywny związek z zadowoleniem górników z ich własnej pracy i z poczuciem, że współpracownicy sprawnie realizują swoje zadania.

\section{THE ASSOCIATION BETWEEN VALUES AND PERFORMANCE IN A MINING CORPORATION. EMPIRICAL STUDY AND INSIGHTS FOR MANAGING BY VALUES (MBV) MODEL}

$$
\text { Keywords }
$$

managing by values, work efficiency, mining industry, company development, management model

\section{Abstract}

The paper presents result of an empirical study in which presence of values among workers of two mining squads characterized by different level of work performance has been compared. Values have been measured by two scales: Mining Values Scale (MVS) and Organizational Culture Assessment Instrument (OCAI). The squad with higher performance had significantly higher level of five out of nine values measured by (MVS); while none of the values measured by OCAI have been differentiating the squads with a statistical significance. The results suggest that Managing by Values (MBV) model for a mining corporation should rather be based on values specific for the mining industry rather than general management value set proposed by OCAI. Research results suggest also an association between presence of certain values and work satisfaction among workers. 